\title{
AKSELERASI INOVASI TEKNOLOGI SPESIFIK LOKASI SEBAGAI STRATEGI PENINGKATAN PRODUKSI DI MASA PANDEMI COVID-19
}

\author{
ACCELERATION OF LOCATION-SPECIFIC TECHNOLOGY INNOVATION \\ AS A STRATEGY FOR INCREASING PRODUCTION IN THE PANDEMIC TIME \\ COVID-19
}

\author{
Roosganda Elizabeth \\ Pusat Sosial Ekonomi dan Kebijakan Pertanian, Kementerian Pertanian \\ Email: roosimanru@yahoo.com \\ (Diterima 29-12-2020; Disetujui 14-1-2021)
}

\begin{abstract}
ABSTRAK
Pangan adalah kebutuhan paling dasar dan utama manusia, yang kecukupan dan kualitasnya turut penentu tingkat intelegensi dan kualitas SDM. Penting dan strategisnya pertanian salah satunya dapat dilihat dari kontribusi nasional/regional (PDB/PDRB). Pertanian tetap sebagai prioritas utama kebijakan pembangunan di Indonesia, terutama di masa pandemi Covid 19 yang masih mewabah sampai saat ini. Tulisan yang merupakan review berbagai data informasi dan literatur terkait ini bertujuan mengemukakan berbagai tingkat penerapan teknologi, tingkat efisiensi teknis di berbagai agro-ekosistem, yang disajikan secara deduktif kualitatif. Terjadinya krisis finansial global (untuk jangka waktu pendek) dan perubahan iklim (untuk jangka waktu panjang) serta bencana nasional (misalnya pandemi Covid 19) mengakibatkan melemah sendi ekonomi terlebih pertumbuhannya, pengangguran meningkat, dan daya beli masyarakat menurun. Kondisi tersebut menyebabkan akses terhadap pangan menurun, sehingga ketahanan pangan diprediksi lebih rawan. Diperlukan penyediaan teknologi dan informasi sesuai kebutuhan, memadainya perangkat kebijakan pemerintah dan operasional, berfungsinya berbagai lembaga pendukung (penelitian, penyuluhan, pemasaran) yang lebih fokus dan berpihak untuk mempercepat pencapaian inovasi teknologi spesifik lokasi. Hal tersebut strategi jitu pemenuhan pangan nasional. Evaluasi kebijakan pembangunan pertanian dari aspek kelembagaan pangan, diperlukan sebagai strategi dan upaya keakuratan perumusan kebijakan dalam mendukung peningkatan produksi beras nasional di masa mendatang.
\end{abstract}

Kata Kunci: masa pandemi Covid 19, spesifik lokasi, inovasi teknologi padi, kelembagaan pangan

\begin{abstract}
Food is the most basic and foremost human need, whose adequacy and quality determine the level of intelligence and quality of human resources. One of the important and strategic aspects of agriculture can be seen from the national/regional contribution (GDP/GDPR). Agriculture remains the main priority for development policies in Indonesia, especially during the Covid 19 pandemic, which is still endemic today. This paper, which is a review of various information data and related literature, aims to present various levels of technology application, levels of technical efficiency in various agro-ecosystems, which are presented in a qualitative deductive manner. The occurrence of the global financial crisis (for the short term) and climate change (for the long term) as well as national disasters (for example the Covid 19 pandemic) resulted in a weakening of the economy, especially its growth, increased unemployment, and decreased purchasing power. This condition causes access to food to decline, so that food security is predicted to be more vulnerable. It is necessary to provide technology and information according to needs, adequate government and operational policy tools, the functioning of various supporting institutions (research, extension, marketing) that are more focused and take sides in accelerating the achievement of location-specific technological innovations. This is the right strategy for fulfilling national food. Evaluation of agricultural development policies from the aspect of food institutions is needed as a
\end{abstract}




\section{AKSELERASI INOVASI TEKNOLOGI SPESIFIK LOKASI \\ SEBAGAI STRATEGI PENINGKATAN PRODUKSI DI MASA PANDEMI COVID-19 \\ Roosganda Elizabeth}

strategy and measures for the accuracy of policy formulation in supporting future increases in national rice production.

Keywords: Covid 19 pandemic period, specific location, rice technology innovation, food institutions

\section{PENDAHULUAN}

Dalam upaya mencegah terjadinya kelaparan dan gejolak ekonomi dan politik, kecukupan pangan beras dengan kualitas dan harga terjangkau merupakan tujuan utama kebijakan pembangunan pertanian; yang jika tidak diimbangi signifikansi laju pertumbuhan produksi pangan domestik berdampak rendahnya ketahanan pangan nasional. Peningkatan produksi pangan (beras) nasional, dapat dilakukan dengan penerapan inovasi teknologi spesifik lokasi dan kebutuhan, peningkatan produktivitas/optimalisasi potensi sumberdaya pertanian; peningkatan luas areal tanam dan pengelolaan lahan; dukungan sarana produksi dan permodalan; jaminan harga gabah, harga jual dan pemasaran gabah dan beras yang memberikan insentif produksi; penurunan konsumsi beras; penyempurnaan manajemen, teknis, data dan informasi; serta peningkatan peran dan kapasitas kelembagaan terkait.

Terkait dengan pandemi Covid-19 yang belum dapat diprediksi kapan akan berakhir, sehingga kegiatan pertanian pun harus "hidup bersama Covid-19”. Hal ini membutuhkan sikap dan perilaku baru (new normal). Dampak Covid-19 utamanya pada keterbatasan mobilitas akibat pembatasan sosial berskala besar, penurunan akses informasi dan infrastruktur serta sumber daya pertanian, serta kesulitan komunikasi dan pendampingan oleh penyuluh pertanian. Pandemi Covid-19 berdampak luas termasuk semua sektor termasuk pertanian. Seluruh bentuk aktivitas menjadi tidak optimal, mulai dari on sampai off farm. Di masa pandemi Covid 19, terindikasi anjloknya permintaan beberapa komoditas serta menurunnya pelayanan penyediaan input sarana produksi, juga mengakibatkan menurunnya kesempatan kerja, tingkat upah tenaga kerja. Dampak yang paling mengkuatirkan adalah menurunnya produksi akibat serangan organisme penyerang tanaman atau OPT dan defisiensi hara karena kurangnya pemeliharaan, terlebih di wilayah pertanian yang beragroekosistem marjinal. Sektor pertanian harus berpacu agar bisa berkontribusi signifikan dalam bisnis pertanian sekaligus mencukupi 
kebutuhan pangan nasional. Kondisi tersebut terkait erat dengan kreativitas inovasi, adopsi teknologi dan pengembangan kelembagaan di tingkat produksi maupun di tingkat pemasaran hingga pengembangan jejaring dan kewirausahaan di sector pertanian (agribisnis dan agroindustri) (beberapa hasil download terkait Covid 19).

Kebijakan pembangunan adalah kontiniutas berbagai rangkaian program terpadu dan berkelanjutan meliputi seluruh sendi kehidupan masyarakat (mikro), bangsa dan negara (makro). Tujuan utamanya mencakup: perluasan pilihan ekonomi dan sosial masyarakat (individu/bangsa); peningkatan dan kontiniutas ketersediaan pemenuhan kebutuhan (pokok) masyarakat (termasuk pendistribusiannya); peningkatan kesejahteraan hidup masyarakat dimana peningkatan standar hidup sebagai salah satu cerminannya. Tujuan (umum) program kebijakan pertanian adalah meningkatkan kehidupan, peningkatan pendapatan dan kesejahteraan petani

Namun sebagai negara agraris, Indonesia nyatanya merupakan pengimpor pangan yang cukup besar, yang merupakan hambatan dalam pembangunan dan menjadi tantangan untuk mewujudkan ketersediaan dan kemandirian pangan bagi bangsa Indonesia. Kemampuan dalam: a) menciptakan nilai tambah; b) akselerasi inovasi teknologi peningkat produksi produktivitas usahatani (kuantitas dan kualitas; dan c) meningkatkan efisiensi pemanfaatan sumberdaya, merupakan tantangan bagi penelitian dan pengembangan pertanian dalam mengantisipasi permintaan pasar di masa datang; dimana tantangan tersebut harus dijawab dengan mempertimbangkan tingkat potensi lestari sumberdaya yang tersedia dan selalu disesuaikan dengan prospek permintaan pasar (Elizabeth, 2017; 2017a; 2019).

Oleh karena itu, diperlukan akselerasi inovasi teknologi padi sesuai kebutuhan dan spesifik lokasi sebagai salah satu strategi pencapaian peningkatan produksi beras nasional yang direalisasikan sebagailangkah kerja yang serius untuk mengoptimalkan sumber daya yang ada dalam rangka memenuhi kebutuhan pangan dalam negeri. Tulisan ini bertujuan untuk mengemukakan secara komprehensif berbagai tingkat penerapan teknologi, tingkat efisiensi teknis di berbagai agro-ekosistem, dengan mereview berbagai data informasi dan literatur terkait yang disajikan secara deduktif kualitatif. 


\section{METODE PENELITIAN}

Terjadinya krisis finansial di era globalisasi, anomali perubahan iklim dan bencana nasional (misalnya pandemi Covid 19) yang mengakibatkan pengangguran meningkat, melemahnya sendi perekonomian dan menurunnya daya beli masyarakat. Kondisi tersebut menyebabkan akses terhadap pangan menurun, sehingga ketahanan pangan diprediksi lebih rawan. Diperlukan penyediaan teknologi dan informasi sesuai kebutuhan, memadainya perangkat kebijakan pemerintah dan operasional, berfungsinya berbagai lembaga pendukung (penelitian, penyuluhan, pemasaran) yang lebih fokus dan berpihak untuk mempercepat pencapaian inovasi teknologi spesifik lokasi; yang merupakan strategi jitu pemenuhan pangan nNasional. Secara deduktif kualitatif dikemukakan dengan komprehensif berbagai tingkat penerapan teknologi, tingkat efisiensi teknis di berbagai agro-ekosistem yang merupakan review berbagai data informasi dan literatur terkait.
HASIL DAN PEMBAHASAN

$\begin{array}{lrr}\text { PERAN DAN } & \text { PROSPEK } \\ \text { PEMBERDAYAAN } & \text { LAHAN }\end{array}$

\section{MARJINAL}

Untuk mengantisipasi berkurangnya lahan pertanian sawah irigasi di Pulau Jawa, dan dalam memperkuat ketahanan pangan nasional, maka pemerintah mengupayakan pemanfaatan lahan marjinal yang masih luas tersebar di luar Jawa. Potensi lahan marjinal (spesifik lokasi) sampai saat ini belum dimanfaatkan secara maksimal yang membutuhkan berbagai inovasi teknologi pengelolaannya. Dengan inovasi teknologi lahan marjinal diharapkan dapat mengatasi berbagai keterbatasan kondisi lahan marjinal, seperti: rendahnya tingkat kesuburan dengan $\mathrm{pH}$ masam dan topografi berlereng yang menyebabkan rendahnya tingkat produksi dan produktivitas serta terbatasnya modal petani sehingga penggunaan input produksi relatif rendah (Musnawar, 2003; Mayunar, dkk. 2005; Portes, 2006; Murtiyeni, dkk. 2007).

Berbagai jenis lahan marjinal terdapat hampir di semua wilayah di Indonesia, dimana masalah kemiskinan umumnya dijumpai di wilayah lahan marjinal, yang memunculkan fenomena sosial sebagai wilayah yang merupakan 
konsentrasi petani miskin. Munculnya gejala kemiskinan tersebut salah satunya disebabkan oleh daya dukung alam yang relatif kurang, prasarana sosial ekonomi yang belum memadai, kelembagaan sosial ekonomi yang belum menjangkau masyarakat setempat serta mutu sumberdaya manusia yang relatif masih rendah. Selama ini pengembangan teknologi di lahan kering, adalah relatif tertinggal bahkan kurang perhatian dibanding lahan irigasi (Hayami, 1987; Mubyarto, 1992; Demitri, dkk. 2006; Andriati, 2007; Dewi, 2007). Petani lahan marjinal umumnya kurang menguasai teknologi pengelolaan lahan yang benar dan sebagian petani bahkan sama sekali belum menggunakan input komersial, seperti pupuk dan pestisida (Putu, dkk. 1998; Elizabeth, 2017 dalam Elizabeth. 2019). Kendala lainnya seperti sedikitnya tenaga kerja terampil, belum berkembangnya kelembagaan usaha tani dan dikuasainya pasar oleh pedagang perantara. Akumulasi dari berbagai kendala tersebut diatas tentunya berpengaruh terhadap rendahnya tingkat penerimaan dan pendapatan petani (Elizabeth, 2010).

Kondisi tersebut terlihat pada dukungan fasilitas umum dan pengembangan informasi serta diseminasi teknologi pertanian sering kali belum dirancang, menjadikan wilayah tersebut semakin terpuruk dan akhirnya masuk perangkap kemiskinan. Meluasnya kemiskinan di wilayah lahan kering, terutama di pedesaan, menunjukkan bahwa tingkat kehidupan masyarakat pedesaan menuntut perhatian dan keseriusan yang lebih besar untuk mengatasinya (Indrajit, 2002; Las, 2004; Santosa, 2011). Suatu alternatif perbaikan insentif bagi petani miskin yang disertai dengan inovasi penggunaan teknologi pertanian dan pemasaran berwawasan agribisnis, merupakan peluang emas untuk meningkatkan pendapatan petani. Namun sebelum mereka mampu melakukan inovasi dan praktek agribisnis, diperlukan adanya dukungan fasilitas umum yang sesuai untuk meningkatkan akses petani terhadap informasi (Faqi, 2004; Elizabeth, 2010; Santosa, 2012; Hutasoit, 2013).

Peningkatan efisiensi pemanfaatan sumberdaya melalui pemanfaatan teknologi unggulan, antara lain dapat meningkatkan keunggulan kompetitif suatu produk pertanian. Disamping itu, potensi pasar serta pertumbuhan permintaan yang pesat merupakan potensi dan peluang untuk mengembangkan produk yang memiliki 
daya saing tinggi. Penerapan rekayasa teknologi pertanian merupakan salah satu strategi yang dilakukan oleh Kementerian Pertanian untuk mewujudkan visi pertanian modern, tangguh dan efisien. Ilmu Pengetahuan dan Teknologi (IPTEK) memainkan peranan penting pada setiap tahapan pembangunan dan pertumbuhan ekonomi, dan menjanjikan kontribusi yang lebih besar terhadap sumberdaya yang tersedia (Anonimous, 2007).

Untuk wilayah yang memiliki lahan tipe pasang surut (Pulau Kalimantan, Papua, Sumsel, dsbnya), umumnya petani menanam padi hanya sekali dalam setahun, yang disebabkan minimal ada dua faktor, yaitu: (1) lahan pasang surut yang sebagian besar punya tipe luapan A sulit ditanami pada musim hujan, karena padinya rawan mati terendam; varietas padi yang digunakan umumnya varietas lokal dengan umur sekitar 7 bulan. Diperlukan upaya pengaturan tata air mikro (TAM), dimana air masuk saat pasang dan air keluar saat surut dapat diatur dengan aliran satu arah mennggunakan pintu air yang sesuai, untuk menjadikan lahan pasang surut bisa ditanami padi dua kali dalam setahun. Sementara itu, disbanding lahan pasang surut, maka ketersediaan air irigasi pada lahan kering sangat terbatas. Oleh karena itu, tidak semua petani pada agroekosistem lahan kering mengusahakan tanaman padi. Bagi petani yang mengusahakan tanaman padi, mereka menanamnya hanya satu kali dalam setahun yakni pada musim penghujan. Faktor-faktor penyebab luas lahan garapan pada lahan kering tidak berpengaruh disebabkan oleh: (1) jarak tanam pada usahatani padi di lahan kering tidak seragam, (2) kondisi hamparan lahan kering heterogen, dan (3) adanya tanaman-tanaman lain (tanaman tahunan, palawija, dan lain sebagainya pada hamparan tersebut). perlu dipertimbangkan dengan sangat seksama mengingat bahwa ekosistem pasang surut pada dasarnya lebih 'fragile' daripada ekosistem pesawahan irigasi teknis maupun ekosistem lahan kering (Swastika, dkk. 2006. Pasaribu, dkk. 2012; Setiawan, 2012).

\section{AKSELERASI INOVASI TEKNOLO- GI SPESIFIK LOKASI}

Tingkat Penerapan Teknologi

\section{Budidaya, Panen Dan Pasca Panen}

Penerapan teknologi sesuai anjuran sangat penting perannya untuk meningkatkan produksi terkait meningkatkan pendapatan dan 
kesejahteraan petani. Secara umum dapat dibedakan atas: (i) Teknologi produksi atau teknologi budidaya tanaman; dan (ii) Teknologi pasca panen. Teknologi pertanian merupakan kombinasi dari penggunaan benih (jenis/varietas), cara pengolahan tanah, penggunaan pupuk, penggunaan tenaga kerja, pemeliharaan tanaman, pengaturan pola tanam, cara penanganan panen dan pasca panen. Selain skala usaha (luas usahatani), tingkat penerapan teknologi sangat menentukan keberhasilan petani dalam mencapai produktivitas maksimum yang dicerminkan oleh penggunaan input (termasuk) dan capaian output. Pengunaan benih, pupuk dan jarak tanam yang sesuai kondisi lokasi (spesifik lokasi) dan anjuran petugas lapang merupakan sebagian dari penerapan teknologi tersebut. Penggunaan pupuk Urea, ZA, SP36 untuk menambah unsur Nitrogen, Sulfur, dan Fosfor dan penggunaan pupuk organik adalah merupakan trik-trik yang diterapkan petani di masing-masing lokasi (Putu, 1998; Rosset, 1999; Toha, 2005; 2007; Elizabeth, 2010).

Jenis pupuk yang digunakan umumnya pada musim kemarau (MK I) sama dengan pupuk pada musim hujan $(\mathrm{MH})$, dengan takaran per ha yang hampir sama. Hanya pupuk kandang yang takarannya lebih tinggi pada musim kemarau, karena mengangkut pupuk kandang pada musim kemarau lebih mudah dibandingkan dengan musim hujan. Relatif lebih rendahnya produktivitas padi musim kemarau diduga disebabkan adanya stress kekurangan air pada fase-fase tertentu dari pertumbuhan vegetatif dan generatif tanaman. Jika pada fase pengisian bulir padi terjadi kekurangan air, maka pengisian bulir tidak akan sempurna, sehingga bobot bulir padi menjadi tidak maksimal, sehingga produktivitas per hektar juga menjadi lebih rendah.

Pada agro-ekosistem lahan kering, petani hanya bertanam padi sekali dalam setahun, yaitu pada musim hujan, karena bergantung pada air hujan. Tingginya takaran benih, dengan luas areal tanam yang sama, karena pada lahan kering petani menggunakan teknologi tanam langsung dengan tugal, tidak menggunakan persemaian. Pada agro ekosistem pasang surut, di Kalimantan Barat, misalnya, petani menggunakan lima jenis pupuk yaitu Urea, SP36, KCl, Phonska, dan pupuk kandang, dengan takaran masing-masing $170 \mathrm{~kg}, 74 \mathrm{~kg}, 56$ $\mathrm{kg}, 71 \mathrm{~kg}$, dan $55 \mathrm{~kg}$ per hektar. Dengan penerapan teknologi tersebut, 
produktivitas padi rata-rata 2,74 ton/ha (Susilowati, dkk. 2010; Pasaribu, dkk. 2012).

\section{Pola Tanam}

Dengan IP 100-200, pola tanam yang umumnya dilakukan adalah padibera-bera; padi-bera-palawija/hortikultura (sayur mayur). Perubahan pola tanam, umumnya sangat dipengaruhi ketersediaan air irigasi ataupun penurunan harga komoditas yang diganti (kenaikan harga komoditas pengganti).

\section{Benih dan Varietas Tanam}

Penggunaan benih berlabel (bermutu) merupakan salah satu teknologi kunci keberhasilan meningkatkan produktivitas padi. Sumber pengadaan benih padi umumnya adalah: hasil produksi sendiri dan sesama petani. Jarang menggunakan benih berlabel mengindikasikan berkorelasi positip penggunaan antara berlabel dengan tidak berlabel dengan sumber pengadaannya. Untuk itu, perlu ditingkatkan frekuensi dan diperluasnya sosialisasi penggunaan benih padi berlabel dan sumber pengadaan benih padi, serta dibarengi dengan program subsidi harga benih padi berlabel. Melalui penggunaan benih padi bermutu (benih berlabel) maka semakin terbuka lebar peluang meningkatkan produktivitas padi nasional.

\section{Pengolahan Tanah dan Cara Tanam}

Kegiatan pengolahan tanah umumnya secara manual tenaga kerja manusia dan atau hand tractor dan tenaga kerja ternak yang tergantung kondisi/letak/struktur tanah (datar, berbukit). Cara tanam padi sawah relatif tidak berubah, tetap dominan dengan sistem tapin ataupun tabela.

\section{Pemeliharaan Tanaman}

Kegiatan penyiangan yang dominan dilakukan dengan menggunakan: tangan, herbisida, landak dan koret, dan kombinasi ketiganya. Perbedaan kedominanan cara tersebut diprediksi berkaitan dengan tingkat ketersediaan tenaga kerja manusia dan modal untuk membayar tenaga upahan.

Pencegahan/pengobatan

HPT umumnya frekuensi penyemprotan dilakukan petani 3-4 kali per musim tanam, yang dipengaruhi tingkat serangan dan dominan dilakukan secara individu, yang dikarenakan kelompok tani tidak aktif. Sistem Pengendalian Hama Terpadu (PHT) relatif belum diadopsi secara baik oleh petani. Pemberantasan hama secara rutin dominan dilakukan sebagai tindakan pencegahan karena menganggap daerahnya merupakan daerah hama. Sedangkan penyemprotan berdasarkan anjuran (dilakukan insidentil 
sesuai situasi serangan hama) relatif lebih rendah.

Pemupukan dilakukan di persemaian (hanya dilakukan pada sistem tanam pindah) dan di pertanaman. Penggunaan pupuk organik sangat dianjurkan karena sangat bermanfaat untuk memperbaiki struktur tanah sebagai sumber hara mikro dan sebagai media untuk perkembangan mikroba tanah. Pupuk organik juga dapat meningkatkan kemampuan tanah memegang air, namun secara agregat tingkat partisipasi petani masih sangat rendah.

\section{Dosis Pupuk dan Partisipasi Penggunaan Pupuk}

Jenis-jenis pupuk anorganik yang digunakan petani dalam pemupukan tanaman padi di lokasi penelitian meliputi: Urea, TSP/SP, KCL, NPK dengan cara disebar, dan sesuai dosis anjuran untuk efisiensi biaya produksi, pertumbuhan tanaman terganggu, menghindari pencemaran unsur hara. Secara lebih rinci, tingkat penerapan teknologi usahatani padi pada lahan pasang surut seperti disajikan pada Tabel 1.
Tabel 1. Tingkat Penerapan Teknologi UT Padi di Lahan Pasang Surut (Kalbar, 2017)

\begin{tabular}{lrrr}
\hline & \multicolumn{3}{c}{ MK 2008 } \\
\cline { 2 - 4 } Komponen Teknologi & N & Rataan & $\begin{array}{c}\text { Simp } \\
\text { Baku }\end{array}$ \\
\hline Luas (ha) & 61 & 0,90 & 0,42 \\
Benih (kg/ha) & 61 & 15,15 & 10,09 \\
Urea (kg/ha) & 60 & 170,11 & 67,605 \\
SP36 (kg/ha) & 28 & 73,54 & 27,32 \\
KCl (kg/ha) & 14 & 56,16 & 24,655 \\
Phonska (kg/ha) & 49 & 70,51 & 28,5 \\
P. Kandang (kg/ha) & 5 & 54,90 & 82,465 \\
TK Pria DK (hok/ha) & 61 & 23,11 & 12,54 \\
TK Wanita DK (hok/ha) & 61 & 17,81 & 10,165 \\
TK Pria LK (hok/ha) & 40 & 6,75 & 6,23 \\
TK Wanita LK (hok/ha) & 51 & 15,44 & 13,955 \\
Produksi Kotor (ku/ha) & 61 & 27,39 & 7,52 \\
Produksi Bersih (ku/ha) & 61 & 23,61 & 7,075 \\
\hline Sumber: Elizabeth. 2017 & & &
\end{tabular}

\section{Panen dan Pasca Panen}

Padi dipanen dengan sabit, perontokkan digebot atau dengan mesin perontok (mesin tresher) dominan dilakukan yang diprediksi berkaitan dengan ketersediaan tenaga kerja di sub sektor tanaman pangan. Hasil panen yang tidak dijual umumnya dibawa dan dijemur di rumah disebabkan biaya pengangkutan gabah relatif lebih murah (jarak tempat penyimpanan ke tempat penjemuran relatif lebih pendek). Teknologi penanganan tahapan kegiatan usahatani yang tepat dan cermat mulai dari proses produksi hingga pemasaran, menjadi salah satu kunci keberhasilan pengusahaan suatu usahatani. Tinggi rendahnya hasil produksi (panen) yang diperoleh sangat tergantung pada proses pengolahan lahan, mulai dari persiapan 
tanam hingga tanam, perlakuan benih, jarak ukuran tanam secara sistematis (ukuran yang pasti, bukan perkiraan), aplikasi gulma, sistem pemupukan dan pengendalian hama yang tepat. Hal ini merupakan hasil (dampak) dari dilaksanakannya penerapan akselerasi inovasi teknologi di masing-masing agroekosistem dan daerah (spesifik lokasi).

Pemberdayaan inovasi teknologi spesifik lokasi tentunya lebih baik hasilnya apabila petani mendapat informasi, teknologi dan inovasi yang tepat guna, yang diperoleh baik melalui kelompok tani maupun melalui penyuluhan dari dinas terkait (kelembagaan pertanian dan pedesaan) secara berkelanjutan. Keberhasilan pelatihan dan pendampingan yang berkelanjutan, yang diperoleh baik melalui kelompok tani maupun melalui penyuluhan dari dinas terkait serta adanya keberpihakan yang bertujuan mensejahterakan petani (Elizabeth, 2016; 2017a). Meskipun sengaja maupun tidak sengaja pemberdayaan SDM dan kelembagaan pertanian dalam prakteknya sering tidak sesuai. Seiring perkembangan era globalisasi, sistem pertanian mengalami pergeseran dan perkembangan (Tjondrodiningrat, 1999 dalam Elizabeth, 2016; 2019), yakni: (i)
Sistem Pertanian Tradisional: misalnya sistem ladang berpindah (bersifat ekstensif, tidak memaksimalkan input) yang tidak sesuai lagi seiring peningkatan kebutuhan lahan usahatani dan semakin meningkatnya pertambahan penduduk; (ii) Sistem Pertanian Modern: yang mengutamakan sistem intensifikasi di areal yang sama, yang mengusahakan varietas baru (lebih unggul/lebih adaptif berbagai kondisi). Sistem ini telah merubah kondisi lahan usahatani menjadi kritis/rusak dan resisten sebagai konsekuensi dampak negatif penggunaan pupuk anorganik, pestisida, dan intensifnya tindakan agronomi dalam jangka panjang. Timbulnya dampak negatif tersebut melahirkan (iii) konsep Sistem Pertanian Berkelanjutan: yang berlandaskan kelestarian lingkungan dan berkelanjutan (environtmentally and sustainable agriculture) (SDGs).

PENTINGNYA PEMBERDAYAAN KELEMBAGAAN DAN SDM
PERTANIAN
Kelembagaan (social institution), mengandung keambiguan antara lembaga dan organisasi yang jelas digambarkan oleh Uphoff (1986), tentang: “What contstitutes an 'institution' is a subject of 
continuing debate among social scientist.... The term institution and organixation are commonly used interchangeably and this contributes to ambiguityand confusion" (Tjondrodiningrat. 1984; 1999; Heizer. 2011). Organisasi yang sempurna adalah organisasi yang melembaga, yang diterjemahkan Koentjaraningrat (1997) dengan istilah 'pranata' ada pula yang 'bangunan sosial'. Kelembagaan merupakan wadah (tempat/keberadaan/berkumpulnya) yang memiliki kejelasan: identitas, kepentingan, aturan/kesepakatan dan struktur/peran/posisi (yang harus dijalankannya secara benar), yang saling berinteraksi untuk kesamaan tujuan. Kelembagaan adalah 'interaksi', apakah berbentuk formal/ nonformal; berpola horizontal/vertical; berbasis ekonomi atau sosial; berlangsung sesaat/lama; merupakan hal yang biasa/hal baru; berpola atau acak; karena perintah atau bukan (Elizabeth. 2008; 2013; 2017).

Pemberdayaan atau empowerment (asal kata empower), sedikitnya memiliki tiga tujuan/definisi, yaitu: 1) to build/make/enable/grow up the convident (membangun/membuat/ meningkatkan percara diri); 2) to give ability, (memberi kemampuan/dimampukan); dan 3) to give power to (memberi kekuatan, mendelegasikan/mengalihkan

kekuasaan/otoritas ke pihak lain). Sedikitnya tiga aspek dalam upaya memberdayakan kelembagaan pertanian dan SDM petani, yaitu; (i) memperkuat potensi atau daya yang dimiliki masyarakat (empowering); menciptakan suasana/iklim yang memungkinkan berkembangnya (enabling) potensi masyarakat; (iii) memberdayakan mengandung pula arti melindungi (Sumodiningrat, 2002; Gunawan. 2002; Edi Suharto, 2004; Elizabeth. 2020). Pemberdayaan adalah upaya untuk membangun daya tersebut dengan mendorong, memotivasikan, dan membangkitkan kesadaran pada potensi yang dimilikinya serta berupaya untuk memperkuat dan mengembangkannya. Konsep pemberdayaan disebut sebagai pembangunan alternatif yang menghendaki demokrasi inklusif, pertumbuhan ekonomi yang tepat, kesetaraan gender dan kesetaraan antargenerasi; "alternative development", yang menghendaki "inclusive democracy, appropriate economic growth, gender equality and intergenerational equaty" (Friedman, 1992; Stefen, 2010 dalam Syahyuti, 2012; 2013; Elizabeth, 2017). 
Meningkatkan produksi dan produktivitas melalui inovasi teknologi di lahan marjinal terkait erai dengan pemberdayaan kelembagaan pertanian dan SDM seoptimal mungkin menjadi tumpuan utama ekonomi petaninya. Dibutuhkan akselerasi program pembangunan dengan sedikitnya kebijakan utama yaitu: (1) pemberdayaan dan peningkatan kinerja kelembagaan pertanian; (2) pemberdayaan dan peningkatan kelembagaan kinerja, kompetensi dan kualitas SDM berbasis pertanian di semua lini/aspek; (3) memberdayakan dan mengembangkan berbagai program pertanian dan subsector terkait yang memperhitungkan kearifan lokal dan spesifik lokasi setiap daerah, yang didedikasikan untuk mendukung dan memfasilitasi sumber penghidupan masyarakat di masing-masing wilayah; (4) membangun pertanian dengan memilih satu atau beberapa komoditas unggulan, supaya semua upaya menjadi terfokus; (5) memanfaatkan endowment (faktor kelimpahan sumberdaya) daerah dengan tetap mempertimbangkan prinsip kelestarian SDGs dan lingkungan sekitar (Elizabeth, 2016; 2019).

Demikian pula perubahan mindset (pola pikir) dengan menanamkan nilainilai budaya modern, seperti kerja keras, hemat, keterbukaan, dan kebertanggungjawaban adalah bagian pokok dari upaya pemberdayaan ini. Peningkatan self farming system and public consumption si petani dalam proses pengambilan keputusan (socialization). Dengan demikian, tujuan akhirnya adalah memandirikan masyarakat tani, memampukan, dan membangun kemampuan untuk memajukan diri ke arah kehidupan yang lebih baik secara berkesinambungan.

Pembangunan pertanian harus secara holistic di semua aspek dan tahapan usahatani dan ketersediaan infrastruktur pendukungnya di lahan marjinal, meliputi: transportasi, pendidikan, kesehatan, komunikasi, ketersediaan pendukung perekonomian lainnya yang terkait prinsip "keberhasilan membangun daerah adalah dengan membangun pertaniannya". Oleh karena itu, pemberdayaan kelembagaan dan SDM pertanian berperan penting dalam inovasi teknologi spesifik lokasi di lahan marjinal terkait mewujudkan pencapaian sepuluh pilar menuju pembangunan pertanian (modern) seperti 4.0, yaitu: 1) pengembangan dan penyediaan alsintan; 2) penjaminan dan penyediaan dana bagi petani; 3) penyediaan benih, pupuk dan pengendalian HPT dengan SDM yang 
mampu menghandle dan mengandalkan teknologi; 4) menyediakan dan memperlancar pemasaran, menjadi penentu keberhasilan semua usaha pertanian, jaminan diperolehnya revenue sebagai penentu diperolehnya keuntungan sebagai pemenuh ekonomi rumahtangga petani; 5) pembangunan jalan pedesaan, JUT, dan jaringan irigasi (infrastruktur pertanian), untuk mempermudah dan memperlancar akses keluar masuknya input-output produksi usahatani; 6) membangun demfarm dan demplot di setiap daerah sebagai pusat percontohan serta berperan sebagai pusat layanan informasi dan penyuluhan serta diseminasi teknologi; 7) membangun dan meningkatkan peran commodity product centre, sebagai pusat penelitian dan pengkajian produk komoditas unggulan dari/dan di masing-masing daerah untuk menjadi pusat pelatihan dan percontohan penerapan paket-paket teknologi, serta menjadi wadah untuk meningkatkan pengkajian dan pengembangan teknologi komoditas unggulannya; 8) perencanaan dan koordinasi; 9) pendampingan, monitoring dan evaluasi; 10) akselerasi diseminasi teknologi kepada para pengguna (petani dan pengusaha) serta diseminasi informasi produk dan ketersediaannya kepada para stakeholders dan konsumen (domestik dan ekspor). Pemberdayaan, pengembangan dan peningkatan kelembagaan pertanian serta kinerja, kompetensi dan kualitas kelembagaan SDM berbasis pertanian di semua lini/aspek sangat dibutuhkan. Kualitas dan kompetensi SDM pertanian yang mampu melaksanakan dan menjalankan serta berinovasi dalam semua instrument program kebijakan pembangunan pertanian diperlukan sebagai dasar kebersinambungan penyusunan rancangan kebijakan pembangunan pertanian yang keberlanjutan (Elizabeth, 2017a; 2019).

Oleh karena itu, dengan telah tersedianya teknologi pertanian, pemicu peningkatan produksi dan produktivitas dengan adanya alih teknologi sebagai inovasi teknologi di lahan marjinal, yang mampu diterapkan petani, melalui diseminasi dan sosialisasi yang terkait peran aktif penyuluhan.

\section{Penutup}

Pembangunan pertanian dan nasional merupakan kontiniutas dari berbagai rangkaian program kebijakan pembangunan yang terpadu dan berkelanjutan, yang meliputi dan menjangkau seluruh sendi kehidupan masyarakat (mikro), bangsa dan negara 
(makro). Inti pembangunan adalah: (i) Kontinuitas dan peningkatan ketersediaan dan pemenuhan kebutuhan (pokok) masyarakat (termasuk pendistribusiannya); (ii) Peningkatan kesejahteraan hidup masyarakat (termasuk petani), yang salah satunya tercermin pada peningkatan standar hidup, yang sangat dipengaruhi oleh: kebijakan program pembangunan pertanian dan program bantuan yang tepat sasaran, inovasi teknologi spesifik lokasi, berperannya keseimbangan implementasi program pembangunan yang mempertimbangkan kearifan lokal dan keberpihakan. Pada aras domestik, pembangunan pertanian kerap berhadapan dengan berbagai tantangan meliputi perbedaan agroekosistem dan budaya tani si petani serta belum berperannya kelembagaan petani dan pangan terutama di wilayah lahan marjinal, yang secara internal mengakibatkan ketidakmenentuan situasi dan kondisi sosial ekonomi pelaku dan kinerja usahatani.

\section{KESIMPULAN DAN IMPLIKASI KEBIJAKAN}

- Teknologi penanganan pengusahaan usahatani padi mulai dari pengolahan lahan, persiapan tanam, tanam, panen, pasca panen, pengolahan hasil, hingga pemasaran mempengaruhi tinggi rendahnya produksi dan produktivitas panen dan menjadi salah satu kunci keberhasilan pembangunan pertanian.

- Produksi yang akan diperoleh sangat tergantung pengolahan lahan, mulai dari persiapan tanam hingga tanam, perlakuan benih, jarak ukuran tanam secara sistematis (ukuran yang pasti, bukan perkiraan) aplikasi gulma dan sistem pemupukan dan pengendalian hama yang tepat.

- Penggunaan benih bermutu (benih berlabel) merupakan salah satu teknologi kunci keberhasilan meningkatkan produksi dan produktivitas usahatani, salah satunya berlabel atau tidaknya benih padi yang digunakan petani berkorelasi positip dengan sumber pengadaannya.

- Teknologi penanganan pengusahaan usahatani padi mulai dari persiapan tanam, panen, pasca panen, pengolahan hasil, hingga pemasaran, menjadi salah satu kunci keberhasilan pembangunan pertanian.

- Perlunya restrukturisasi peran aktif kelompok tani sebagai salah satu bentuk kelembagaan sosial masyarakat dan akses informasi petani di pedesaan. 
- Perlunya program dan kebijakan pemerintah terkait dengan peningkatan akses petani dan pelaksanaan penerapan akselerasi inovasi teknologi dengan mempertimbangkan spesifik lokasi.

\section{DAFTAR PUSTAKA}

Andriati dan Wayan Sudana. 2007. Keragaman dan Analisis Finansial Usahatani Padi (Kasus Desa Primatani, kabupaten karawang, Jawa Barat). Balai Besar Pengkajian dan Pengembangan Teknologi Pertanian Bogor, Jurnal P2TP Vol. 10 No. 2, Juli 2007 Hal. 106-118.

Anonimus, 2007. Peraturan Menteri Pertanian

No.40/Permentan/OT.140/04/2007 tentang Rekomendasi Pemupukan N,P, Dan K Pada Padi Sawah Spesifik Lokasi, Departemen Pertanian, Jakarta.

Demitria.D., Harianto, Sjafri.M, Nunung. 2006. Peran Pembangunan Sumberdaya Manusia dalam Peningkatan Pendapatan Rumah Tangga Petani di Daerah Istimewa Yogyakarta. Forum Pascasarjana. IPB. Vol.33. No.3. Juli 2010. hal. 155-164.

Dewi.S., Alam dan Haris. 2007. Analisis Titik Impas dan Sensitivitas Terhadap Kelayakan Finansial Usahatni Padi Sawah. Jurnal P2TP Vol. 10 No. 2, Juli 2007, hal, 119125.

Elizabeth, R. dan I. S. Anugrah. 2010. Sistem Kelembagaan Komunitas Petani Sayuran Di Desa Baturiti, Tabanan, Provinsi Bali. Seminar Nasional Pusat Sosial Ekonomi dan Kebijakan Pertanian. (PSE-KP).
Bogor. Badan Litbang Pertanian. Departemen Pertanian. Jakarta.

Elizabeth. R. 2017. Restrukturisasi Implementasi dan Efektivitas Program Pembiayaan Menuju Peningkatan Kapasitas dan Produktivitas Beras. Journal of Agricultural Scienties. UNES. (Universitas Ekasakti). Padang Sumatera Barat. Volume 1. Issue 1. February 2017. ISSN Cetak: 25495909. ISSN Online: 2549-5917.

Elizabeth. R. 2017a. Akselerasi Pemberdayaan Dan Peningkatan Kompetensi Dalam Sistem Produksi Untuk Mengatasi Permasalahan Ekonomi Di Indonesia. Volume 2. Issue 1. June 2017. ISSN Cetak: 2528-5556. ISSN Online: 2528-6226.

Elizabeth, R. 2016. Strategi Terwujudnya Pertahanan Pangan Nasional Melalui Tercapainya Kedaulatan Pangan Dan Keseimbangan Ekonomi Perdesaan. Seminar Nasional Padi 2016, pada tanggal 31 Agustus 2016 di Balai Besar Penelitian Tanaman Padi, Sukamandi, Jawa. Seminar Nasional Padi 2016, pada tanggal 31 Agustus 2016 di Balai Besar Penelitian Tanaman Padi, Sukamandi, Jawa Barat.

Elizabeth, R. 2008. Diagnosa Kemarjinalan Kelembagaan Lokal untuk Menunjang Perekonomian Rakyat di Pedesaan. Jurnal SOCA. Vol. 8. No. 2. Juli 2008. hal. 58-64. Jurusan Sosial Ekonomi Pertanian. Universitas Udayana. Bali.

Fagi, A.M. 2004. Penelitian Padi Menuju Revolusi Hijau Lestari. Dalam: Inovasi Pertanian Tanaman Pangan. A.K. Makarim, Hermanto dan Sunihardi (Eds). Puslitbangtan. Bogor.

Hayami, Y. dan M. Kikuchi. 1987. Dilema Ekonomi Desa. Suatu 
Pendekatan Ekonomi Terhadap Perubahan Kelembagaan di Asia. Yayasan Obor. Indonesia. Jakarta.

Heizer J, B Render. 2011. Manajemen Operasi. Edisi 9. Sungkono, Chirswan, Penerjemah. Jakarta (ID): Salemba Empat. Terjemahan dari: Operation Management.

https://www.merdeka.com/peristiwa/dataterkini-jumlah-korban-virus-coronadi-indonesia.html

https://www.cnnindonesia.com/nasional/2 0200429062046-20-498263/calonepisentrum-corona-baru-semarangsurabaya-dan-makassar

https://nasional.kontan.co.id/news/pengan gguran-akibat-COVID-19-bisamelebihi-hitungan-pemerintah

https://nasional.kontan.co.id/news/pengan gguran-akibat-COVID-19-bisamelebihi-hitungan-pemerintah

https://finance.detik.com/berita-ekonomibisnis/d-5011381/phk-takterbendung-bahaya-gelombangkemiskinan-baru.

Hutasoit, R. Rusdiana, S, dan Elizabeth, R. 2013. Potensi Sumberdaya Lokal dalam Analisis Ekonomi. Seminar Nasional "Pengembangan Ekonomi Kreatif Berbasis Komoditas Pertanian di Indonesia", Universitas Sebelas Maret (UNS), Surakarta, Mei 2013. ISBN 978602-19392-1-5.

Indrajit RE, Djokopranoto R. 2002. Konsep dan Aplikasi Business Process Reengineering. Jakarta. Grasindo.

Las, I. N. Widiarto, B. Suprihatni. 2004. Perkembangan Varietas dalam Perpadian Nasional. Inovasi Pertanian Tanaman Pangan. A.K. Makarim, Hermanto dan Sunihardi (Eds). Puslitbangtan. Bogor. Hal 125.

Mayunar, Sri Redjeki, Pepi Nur Susilawati, Pramu Sunyoto, Achmad Basyarie, Waspada,
Undang Subarna dan Didi Urnadi, 2005. Pengkajian Sistem dan Model Pengelolaan Lahan sawah Irigasi Dalam Upaya Peningkatan Produksi Padi (laporan Kegiatan). Balai Pengkajian Teknologi Pertanian, Banten.

Musnamar, E. I. 2003. Pupuk Organik padat: Pembuatan dan Aplikasi. Seri Agritekno, Penebar Swadaya, Jakarta.

Murtiyeni, Elizabeth. R, Broto.W, Sofiyan.I, Isbandi dan R.Asniru. 2007. Pemanfaatan Limbah Pertanian dan Peternakan sebagai Pupuk Organik Guna Mengatasi Pencemaran Lingkungan di Lahan Marjinal di Donggala. Laporan Akhir Penelitian, Balai Penelitian Ternak bekerjasama dengan Proyek Peningkatan Pendapatan Petani Melalui Inovasi (P4MI), Badan Litbang Pertanian, Kebutuhan Informasi, hal. 28-37.

Pasaribu, S., A. Agustian. R. Elizabeth., J. Hestina. 2012. Kajian Alternatif Skema Pembiayaan APBN Untuk Mendukung Swasembada Beras. LHP. PSEKP. 2012.

Putu, W. I. H., J. Purnomo dan Sukristyanubowo.1998. Pengaruh pengelolaan bahan organik dan tingkat pemupukan dalam usaha mempertahankan produktifitas tanah etisol Jambi. Prosiding Pertemuan Pembahasan dan Komunikasi Hasil Penelitian Tanah dan Agroklimat Bidang Kimia dan Biologi Tanah. Bogor.

Syahyuti. 2003. Bedah Konsep Kelembagaan. Strategi Pengembangan dan Penerapannya dalam Penelitian Pertanian. Puslitbang Sosek Pertanian. Bogor. 123 hal.

Sukoharjo. 2007. Laporan Akhir Inventarisai dan Seleksi Kreativitas dan Inovasi Masyarakat 
(KRENOVA) Kabupaten

Sukoharjo Tahun 2007, BAPPEDA

Sukoharjo, Sukoharjo.

Stefen. S. 2010. Sumber Daya Manusia

Pertanian dan Indutrialisasi.

Summaries 1 - 10 dari 116.

kunjungan ke 2.462

http://id.shvoong.com/social-

sciences/1728774-sdm-pertanian-

dan-

industrialisasi/http://id.shvoong.co

m/authors/drs.-stefan-sikone/

ditampilan pada tanggal $27 \mathrm{Okt}$

2010 19:21:48 GMT.

Susilowati, S.H., Budiman H., Muchjidin

R., Adreng P., Sugiarto, Supriyati, Supadi, Amar K. Z., Bambang W., Herman S., Tri B. P. Roosganda Elizabeth, Deri H., Tjetjep N., Chaerul M.,Mohamad M., Muhammad I. Rizma A., 2009. Panel Petani Nasional: Indikator Pembangunan Pertanian dan Pedesaan. Laporan Hasil Penelitian. Pusat Penelitian Sosial Ekonomi Pertanian. Departemen Pertanian. Bogor.

Swastika, D. K. S, J. Wargiono, B. Sayaka, A. Agustian, dan V. Darwis. 2006. Kinerja dan Prospek Pembangunan Pertanian Tanaman Pangan di Indonesia. Seminar Kinerja Pembangunan Pertanian 2006 dan Prospek 2007. Pusat Analisis Sosial Ekonomi dan Kebijakan Pertanian. Bogor.

Portes, A. 2006. Institution and Development: A Conceptual Reanalysis [Institusi dan Pembangunan: Sebuah AnalisisUlang Konseptual]. Population and Development Review 32 (2): 233i 262.

Rosset, P.M. The Multiple Functions and Benefits of Small Farm Agriculture In the Context of Global Trade Negotiations. By Ph.D. September 1999. Food
First/The Institute for Food and Development Policy Oakland, CA USA. http://www.foodfirst.org/ node/246.

Santosa, D.A. 2011. RUU Kedaulatan Petani. Harian Kompas, 8 September 2011.

Santosa, D.A. 2012. Benih Kedaulatan Petani. Harian KOMPAS, 4 Juni 2012

Setiawan, U. Deputi Sekretaris Jenderal Konsorsium Pembaruan Agraria (KPA). 17 April, Hari Perjuangan Petani Sedunia. Copy-right Sinar Harapan 2003. (http://www.terranet.co.id/beritanya. php?id=11639, 21 April 2005).

Syahyuti. 2012. Kelemahan Konsep dan Pendekatan dalam Pengembangan Organisasi Petani: Analisis Kritis terhadap Permentan No. 273 tahun 2007. Majalah Analisis Kebijakan Pertanian Vol .10 No.2 tahun 2012).

Syahyuti. 2012. 35 tahun Berkarya untuk Petani: Sinopsis Penelitian PSEKP periode 1976 i 2010. IAARD Press.

Syahyuti. 2013. Pemahaman Terhadap Petani Kecil Sebagai Landasan Kebijakan Pembangunan Pertanian. Forum Agro Ekonomi. Vol.31 No.1 Juli 2013:15-29. Pusat Sosial Ekonomi dan Kebijakan Pertanian. Bogor. Kementerian Pertanian. Jakarta

Tjondronegoro, S.M.P. 1984. Sosial Organization and Planned Development in Rural Java: A Study of the Organizational Phenomenon in Kecamatan Cibadak, West Java and Kecamatan Kendal, Central Java, Singapore: Oxford University Press. Tjondronegoro, S.M.P. 1999. Revolusi Hijau dan Perubahan Sosial di Pedesaan Jawa. Dalam buku Keping-Keping Sosiologi dari 
Pedesaan. Jakarta: Direktorat Jenderal Pendidikan Tinggi, Departemen Pen- didikan dan Kebudayaan RI. Hal. 22.

Toha, H M, Prayitno, I Yuliardi dan K Permadi. 2005. Penelitian dan pengkajian model pengembangan pengelolaan tanaman dan sumberdaya terpadu (PTT) padi gogo. Laporan tahunan 2004. Balai Penelitian Tanaman Padi, 25 hal.
Toha, H M. 2007. Peningkatan produktivitas padi gogo melalui penerapan pengelolaan tanaman terpadu dengan introduksi varietas unggul. Penelitian Pertanian, Puslitbang Tanaman Pangan, Badan Litbang Pertanian. 26(3): 180-187. 